\title{
Is The Food Industry Taking A Proactive Stance On Environmental Issues? Results From An Empirical Analysis
}

María del Val Segarra-Oña, Ph.D., Universitat Politècnica de València, Spain Luis Miret-Pastor, Ph.D., Universitat Politècnica de València, Spain Angel Peiró-Signes, Ph.D., Universitat Politècnica de València, Spain

\begin{abstract}
Food industry is the largest industrial sector in both, the EU and the U.S., feature that persists in Spain where it accounts for $17 \%$ of total industrial sales, $7 \%$ of GDP, and employs over 500,000 people. However, different analysis warn about the loss of competitiveness that this sector can suffer in the next years. In a global economy in which Europe has lost a great part of its price advantage, innovation and, going beyond this term, eco-innovation, is one of the resources that can maintain or increase competitiveness. The aim of the present paper is to make a contribution, trying to understand the role of proactive environmental management tools and incremental organizational eco-innovation in creating value in the Spanish food sector by means of an analysis of the effects of the ISO 14001. We analize the whole industry segmented by size using quantitative methods. The data analysed in this research seem to be in agreement with other studies. Results show that firms with proactive practices exhibited a significantly positive economic performance at the industry analized.
\end{abstract}

Keywords: Environmental Certification; Spanish Food Industry; Economic Performance

\section{INTRODUCTION}

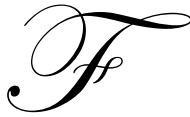

ood industry faces a series of structural changes: first, we detect a growing tendency to sell processed foods (Ruan and Gopinath, 2008), secondly, shows major and rapid changes in consumer preferences caused by economic development, changes in population structure and the emergence of new lifestyles (Wijnands et al. 2008) and, finally, important technological changes in areas such as biotechnology or technology information systems, which are leading to new products and new methods on how to organize food supply chain (Wijnands et al. 2008).

Taking care of the environment can be a competitive advantage that allows the firm to reach the access to new markets and differentiate themselves from competitors (Porter and Van der Linde, 1995, Esty and Winston, 2006). In this regard, in recent years has been observed a significant increase in the number of companies with ISO 14001 environmental certification. In the case of the Spanish food industry, it has grown from 3 companies certified (with EMAS or ISO 14001) in 1997 to 298 in 2008, representing 3.45\% of total registered companies in Spain (Muñoz and Sosvilla, 2010). In this context, many companies decide to go beyond the formal legal requirements and take a proactive stance on environmental issues (Segarra-Oña et al. 2011).

Standardised environmental management can be classified according to the criteria of the recognised authorities (Oslo Manual, 2005) as incremental organizational innovation. Management of sustainable development, the implementation of quality control mechanisms that assure that products and services comply with stipulated standards of excellence related to the principles and practices of sustainability (Weaver and Lawton, 2007) and value creation through environmental certification (Daviron and Vagneron, 2011) and especially through the ISO 14001 
(McKeiver and Gadenne, 2005; Raines, 2002) become crucial. In this context, the food industry has the opinion that eco-innovation has to be considered as a key for increasing their competitiveness (CIAA, 2010).

There are extensive literature that examines the economic impact of the companies that implement ISO 14001 system. Melnyk et al. (2002) or Montabon et al. (2002) found empirical evidence to say that the ISO 14001 improves both the environmental and the business image. Economic improvements occur through several pathways, such as cost reduction (Florida and Davison, 2001), improving the reputation (Esty and Winston, 2006), or increases in productivity (Bleischwitz, 2010), although the interest of the academic community about the issues of environmental management in Food Industry is still scarce (Galdeano-Gómez, 2009) and despite the changes in preferences consumer and technology, different authors (Bellesi et al. 2005) lead to assert that the food industry is an industry where environmental issues and food safety will play a key role in the coming years, especially in developed countries.

\section{OBJECTIVES AND STRUCTURE OF THE PAPER}

Certification can be defined as a voluntary checking process that audits and gives written assurance that a process, product or service meets a specific set of standards (Bhaskaran, 2006, Miret et al. 2011). These standards, in regard to environmental management, provide guidance to implement an Environmental Management System (EMS). However, there is a lack of research on the correlation between ISO 14001 certificated firms and their economic performance in crisis situations. This paper studies the food industry from an aggregate level.

The aim of this work consists on evaluating the impact of the implementation of an environmental management tool, the ISO 14001, in food companies on the firms' business results. Our main hypothesis states that Environmental management through the ISO 14001 in food companies is linked to economic performance. From this line of study, we will determine whether it is possible to identify moderating factors that influence this link.

A review of the existing literature on environmental will be made and the implementation of environmental management systems at the food industry, trying to identify the most important aspects that affect the economic performance of food companies. An analysis and evaluation of a food companies sample that have implemented the ISO 14001 will then be made, as compared to a sample of companies that have not done so. Empirical relationships will be established between environmental management with the ISO 14001 and business performance. After the statistical analysis and discussion of the results, the conclusions drawn from the study will be given.

\section{THE SPANISH FOOD INDUSTRY'S MAIN FACTS}

The Spanish food sector is one of the three pillars of the Spanish industry, together with automobile and chemical industry. A brief description of this sector is shown, based on the information obtained from the FIAB, Spanish federation of food and beverage industry, (Muñoz and Sosvilla, 2010). The food and beverage industry had in Spain in 2009, 30650 companies. Among these, 99, 2 \% are considered SME's (Small and medium enterprises) and only $0,8 \%$ Big companies. This sector employs $17 \%$ of the total jobs on the industry. The Spanish sector of the food industry had 84,600 million Euros net sales in 2009; this represents $14 \%$ of the industry's net sales and $8.04 \%$ of Spanish GDP. In terms of foreign trade, the export value accounted in 200915053 million euros, compared to a value of imports of 14.787 million euros. This represented a positive trade balance in 2009 of 266 million euros. This sector helps to level the foreign trade balance in Spain. This sector has a higher rate of innovative companies than in the rest of the Spanish economy.

\section{METHODOLOGY}

\subsection{The sample}

It is important to identify the characteristics of firms since this affects their environmental management practices. Although at first we had thought of adopting smaller and more homogeneous regions, we considered that analysing a broader scenario could help us to obtain better results. Given the strategic importance of the food industry in Spain, we included firms from all the Spanish regions in the study. 
Data referring to food firms with environmental certification were taken from the IHOBE database, (considering CNAE codes 10, food industry and 11 beverage industry) which consists of a monthly updated comprehensive list of Spanish companies certified according to the ISO 14001 standard, with a search system by sector, National Spanish Activities Classification, CNAE, or province. Affiliate level information includes name of the affiliate; host-region and economic activity as defined by the CNAE codes, the address, and the certifying organization.

Of the 6.118 Spanish food companies identified, economic information was obtained from the SABI database for the year 2008. Of these firms, only 150 had ISO 14001 certification. Table 1 shows the data divided into total companies and companies with ISO 14001 certification.

Table 1. Classification of firms studied according to its size

\begin{tabular}{|l|c|c|c|}
\hline & With ISO & Without ISO & Total \\
\hline$<\mathbf{5 0}$ employees & $69(1,27 \%$ of total $)$ & 5354 & 5423 \\
\hline $\mathbf{5 0 - 2 4 9}$ employees & $46(8,07 \%$ of total $)$ & 524 & 570 \\
\hline$>\mathbf{2 5 0}$ employees & $35(28 \%$ of total $)$ & 90 & 125 \\
\hline Total & $150(24,5 \%$ of total $)$ & 5968 & 6118 \\
\hline
\end{tabular}

Source: IHOBE and SABI databases.

Data in the table above confirm the relationship between size and environmental certification. Although in absolute numbers most certified companies belong to small and medium enterprises (115), these figures represent only $1.27 \%$ of total existing small businesses in the industry and $8.07 \%$ of medium, while $28 \%$ of large companies are certified.

We can say that the percentage of certified firms goes up with size. Thus, only the $1.27 \%$ of small firms are certified, a percentage that rises to $8.07 \%$ for medium enterprises and reaches $28 \%$ of large enterprises. According to the segmentation, four separate studies will be made, one for the food industry in general (analyzing first hypothesis) and one for each of the three segments in which we divide the industry by size of firms (which will serve to validate the second of the hypotheses).Company size measured by number of employees (European Commission, $2003^{1}$ ).

\subsection{Data analysis}

To validate our hypotheses, we applied the ANOVA test that can detect mean differences across business functions comparing ISO 14001 certified with non certified firms, using specific performance indicators such as Trading Income, (TI), net sales (NS), size by number of employees (SZ), Profit Margin, (PM), Earnings on sales before interest, taxes, depreciation and amortization, (EBITDA), Ordinary incomes before taxes (OIBT), and Profit per employee (PPE).

The same indicators had previously been used to analyse financial performance in Spain (Albors et al. 2009). To construct the indicators, information was taken from the SABI database and was subsequently processed.

The ANOVA analysis seeks to break down the variability in a study into independent components that can be assigned to different causes. It is a statistical technique designed to analyse the significance of the mean differences of the different populations, and as such, it is considered as an extension of the means difference test, and is used to study the relationship between nominal, ordinal and interval variables (Hair et al. 1998). The ANOVA technique indicates whether or not we reject the null hypothesis that reflects the equal means value for each $\alpha$ level of significance. In this way we confirm whether the mean of the variable performance is significantly different for the firms according to their ISO 14001 environmental certification. The database was analysed using SPSS.17.0. (See Table 2).

${ }^{1}$ On 6 May 2003 the Commission adopted Recommendation 2003/361/EC 
After analysing the overall mean value of the six studied variables, it was found that all of them revealed significant differences between firms with ISO 14001 certification and those without.

Table 2. Comparison of means (one-way ANOVA) for economic performance

\begin{tabular}{|c|c|c|c|c|}
\hline ANOVA & ISO 14001 & Mean & F & Sig. \\
\hline & With ISO & $1,06 \mathrm{E}+05$ & 628,360 & $0,000^{*}$ \\
\hline TI & Without ISO & 7050,68158 & & \\
\hline & Total & 9457,24156 & & $0,000^{*}$ \\
\hline NS & With ISO & $1,03 \mathrm{E}+05$ & 621,174 & \\
\hline & Without ISO & 6969,42915 & & $0,000^{*}$ \\
\hline & Total & 9318,28039 & & \\
\hline SIZE & With ISO & 361,41 & 559,235 & $0,000^{*}$ \\
\hline & Without ISO & 29,82 & & \\
\hline EBITDA & Total & 37,89 & & \\
\hline & With ISO & $1,15 \mathrm{E}+04$ & & \\
\hline & Without ISO & $4,68 \mathrm{E}+02$ & & $0,000^{*}$ \\
\hline & Total & $7,36 \mathrm{E}+02$ & & \\
\hline
\end{tabular}

*Significance at the 0,05 level is shown in italics.

It is interesting to observe how the mean values of all of them are considerably higher than those in noncertified firms. Considering the mean size gives some indication of the relationship between size, process organisation and economic performance. This indication is supported by the EBITDA and the PPE values.

\section{CONCLUSIONS}

First of all, our findings showed that the use of ISO14001 as an environmental management tool had a significant impact on several economic performance variables, which led us to conclude that there is a direct relation between ISO 14001 and corporate performance, thus validating our main hypothesis, which stated that ecoinnovation in environmental management by the application of ISO 14001 contributes to value creation in the food Spanish industry by improving business results.

The ANOVA analysis revealed significant differences in economic performance in the total sample, composed of all food companies with ISO 14001 environmental certification.

A large number of empirical studies have confirmed that the use of formal systems for achieving greater coordination characterises evolutionary periods (Greiner, 1997). This could explain why there is a direct relation between applying innovative organizational systems and better business management and performance. The data analysed in this research seem to be in agreement with other studies. The results show that firms with proactive practices exhibited a significantly positive economic performance (Aragón-Correa et al. 2008; Martín-Tapia et al. 2010).

To sum up, our analysis shows that the best performing firms in the Spanish food industry are those that have adopted the ISO 14001 proactive environmental management tool, considering size acts as a moderating factor. 
Furthermore, we would like to point out that one of the limitations the research holds is that it has only been made from a quantitative analysis perspective. Future research will focus on the use of different methodologies. An in-depth case study will be necessary to obtain further information on the results obtained.

\section{ACKNOWLEDGMENTS}

The authors acknowledge the financial aid received from the Spanish Ministry of Science and Innovation through research project reference no. EC02008-05895-C02-01/ECON and from the PAID-06-2011. Universidad Politécnica the Valencia funded a sabbatical research 2011-2012 course of M. Segarra.

\section{AUTHOR INFORMATION}

María del Val Segarra-Oña, $\mathrm{PhD}$ in Management and Degree in Industrial Engineering by the Universitat Politècnica de València. Associate Professor in Innovation, Competitivenees, Regional Development and Industrial Policies at the Faculty of Industrial Engineering at the Universitat Politècnica de València (Spain). Marival Segarra is an Associate Professor at the School of Industrial Engineering at the Universidad Politécnica in Valencia. Research Interest: The relations between environmental proactivity and eco-innovation and economic performance of companies, applied to industrial and service sectors. Phone +34 963877000-Ext 76844; Fax +34 963877689; Email: maseo@omp.upv.es.

Luis Miret-Pastor, $\mathrm{PhD}$ in Management and Degree in Economics by the Universitat Politècnica de València. Assistant Professor in Natural Resources Management at the Gandia Campus of the UPV. Research Interest: Ecoinnovation, clusters and tourism. E-mail: luimipas@esp.upv.es.

Angel Peiró-Signes, $\mathrm{PhD}$ in Business Administration and Degree in Industrial Engineering by the Universitat Politècnica de València. Assistant Professor in Analytical Accounting in Manufacturing firms and Strategic Management and Business Policy at the Faculty of Business Administration at the Universitat Politècnica de València (Spain). Research Interest: Environmental proactivity and eco-innovation and economic performance of companies, applied to industrial and service sectors. E-mail: anpeisig@omp.upv.es.

\section{REFERENCES}

1. Albors-Garrigós, Marquez P B, Segarra-Oña M (2009) Internet como herramienta de creación de valor en sectores maduros. El caso de los productores y distribuidores cerámicos en España. Bol. Soc. Esp. Ceram. y Vidrio, 48:273-278

2. Aragón-Correa J A, Hurtado-Torres N, Sharma S, García-Morales V J (2008) Environmental strategy and performance in small firms: A resource-based perspective. Journal of Environmental Management 86: 1, $88-103$.

3. Bhaskaran S (2006) Incremental Innovation and Business Performance: Small and Medium-Size Food Enterprises in a Concentrated Industry Environment. Journal of Small Business Management 44:64-80.

4. Bellesi F, Lehrer D, Tal A (2005) Comparative Advantage: The Impact of ISO 14001. Environmental Certification on Exports. Environmental Science and Technology 39(7):1943-1953.

5. Bleischwitz R (2010). International economics of resource productivity. Relevance, measurement, empirical trends, innovation, resource policies. Int Econ Econ Policy 7:227-244.

6. CIAA. Confederation of the Food and Drink Industries in the EU (2010) Supporting the competitiveness of the European food and drink industry. CIAA Competitiveness Report 2010, Brussels.

7. Daviron B, Vagneron I (2011) From Commoditisation to De-commoditisation and Back Again: Discussing the Role of Sustainability Standards for Agricultural Products. Development Policy Review 29, 1:91-113.

8. Esty D C, Winston A S (2006) Green to Gold, How smart companies use environmental strategy to innovate, create value, and build competitive advantage. John Wiley \& Sons. Hokoben, New Jersey.

9. Florida R, Davison D (2001) Gaining from green management: environmental management systems inside and outside the factory. California Management Review 43(3): 64-84.

10. Galdeano-Gomez E (2009) Exporting and Environmental Performance: A Firm-level Productivity Analysis. The World Economy, 33,1, 60-88. 
11. Greiner L E (1997) Evolution and Revolution as Organizations Grow: A company's past has clues for management that are critical to future success", Family Business Review 10(4). Reprinted by permission of Harvard Business Review. From "Evolution and Revolution as Organizations Grow" by Larry E. Greiner, July-August 1972.

12. Hair J F, Anderson R E, Tatham R L, Black W C (1998) Multivariate Date Analysis, 5th ed., Prentice-Hall, Englewood Cliffs, NJ

13. Martín-Tapia I, Aragón-Correa J A, Rueda-Manzanares A (2010) Environmental strategy and exports in medium, small and micro-enterprises. Journal of World Business 45:266-275.

14. McKeiver C, Gadenne D (2005) Environmental management systems in small and medium business. International Small Business Journal 23:513-537.

15. Melnyk S, Sroufe R, Calantone R (2002) Assessing the impact of environmental management systems on corporate and environmental performance. Journal of Operations Management 336:1-23

16. Miret-Pastor L, Segarra-Oña M, Peiró-Signes A (2011) Environmental certification as a tool to measure and promote ecoinnovation in the tourist sector. Research Studies in Tourism and Environment, Nova Publishers, Hauppauge, NY, USA.

17. Montabon F, Melnyk S, Sroofe R, Calantone R (2002) ISO 14000: Assessing its perceived impact on corporate purchasing performance. The Journal of Supply Chain Management 36(2):4-15.

18. Muñoz C, Sosvilla S (2010) Informe Económico 2009. Federación Española de Industrias de Alimentación y Bebidas. FIAB, Madrid.

19. Oslo Manual (2005) Guidelines for Collecting and Interpreting Innovation Data, OECD- EUROSTAT, Luxembourg.

20. Porter M E, Van der Linde C (1995) Toward a new conception of the environment competitiveness relationship. Journal of Economic Perspectives 9(4):97-118.

21. Raines S S (2002) Implementing ISO-14001: An international survey assessing the benefits of the certification. Corp. Environ. Str. 9:418-426.

22. Ruan J, Gopinath M (2008). Global productivity distribution and trade liberalisation: evidence from processed food industries. Eur. Rev. Agric. Econ. 4:439-460.

23. Segarra-Oña M, Peiro-Signes A, Albors-Garrigos J, Miret-Pastor L (2011) Impact of innovative practices in environmentally focused firms. Moderating factors, Int. J. Environ. Res. 5(2), 425-434.

24. Weaver D B, Lawton L J (2007) Twenty years on: The state of contemporary ecotourism research. Tourism Management 28:1168-1179.

25. Wijnands J H M, Bremmers H J, Van der Meulen B M J, Poppe K J (2008) An Economic and Legal Assessment of the EU Food Industry's Competitiveness. Agribusiness 24(4):417-439. 